\title{
Drainage of Bank Storage in Shallow Unconfined Aquifers
}

\author{
Abdelkader Djehiche ${ }^{1}$, Mustapha Gafsi ${ }^{1}$ and Konstantin Kotchev ${ }^{2}$ \\ ${ }^{1}$ LRGCU Amar Telidji, Laghouat, \\ 2Ploytechnique, Sofia, \\ ${ }^{1}$ Algeria \\ ${ }^{2}$ Bulgaria
}

\section{Introduction}

The present work concerns subsurface drainage systems. The problems of surface and subsurface draining excess water from the canal or river are the major preoccupation of many researchers for at least 50 years; therefore we devoted this study to find appropriate solutions for problems encountered in the drainage of bank storage in shallow unconfined aquifers.

It is necessary to develop special processes such as the drains, the filters and to choose the type of the most effective drain to drain excess water from the canal. We have performed a study on a reduced model, of a homogeneous soil with trench drain on an impervious foundation, and we have proposed a correlation to determine the best position of the trench drain in the homogeneous soil. The water level in the trench drains can be directly determined for a given head of water in the canal, slope of the canal and the permeability coefficient, so that the seepage analysis is simplified to a certain degree and the accuracy is also satisfied based on the new approach. Finally comparative studies between experimental and numerical results using [SEEP] software were carried out.

\section{Horizontal drainage}

\subsection{Steady and parallel flow in unconfined aquifers}

In this section, we discuss the flow of groundwater to trench drains under steady state conditions. The steady-state theory is based on the assumption that the rate of recharge to the groundwater and evaporation is null.

Figure 1 shows a typical cross-section of a drainage system under this condition.

To describe the flow of groundwater to the trench drains, we have to make the following assumptions:

- Two-dimensional flow. This means that the flow is considered to be identical in any cross-section perpendicular to the drains; this is only true for infinitely long drains; 
- Homogeneous and isotropic soils with a permeability $K$. Thus we ignore any spatial variation in the hydraulic conductivity within a soil layer.

Most drainage equations are based on the Dupuit-Forchheimer assumptions (Ritzema, 1994):

Dupuit -Forchheimer equation:

$$
\frac{K}{2}\left[\frac{\vartheta^{2}(h)^{2}}{\vartheta x^{2}}+\frac{\vartheta^{2}(h)^{2}}{\vartheta y^{2}}\right] \pm q=0
$$

Where $\mathrm{q}=$ recharge rate per unit area $\left(\mathrm{m} /\right.$ day $\left./ \mathrm{m}^{2}\right)$ and $\mathrm{K}=$ hydraulic conductivity of the soil (m/ day)

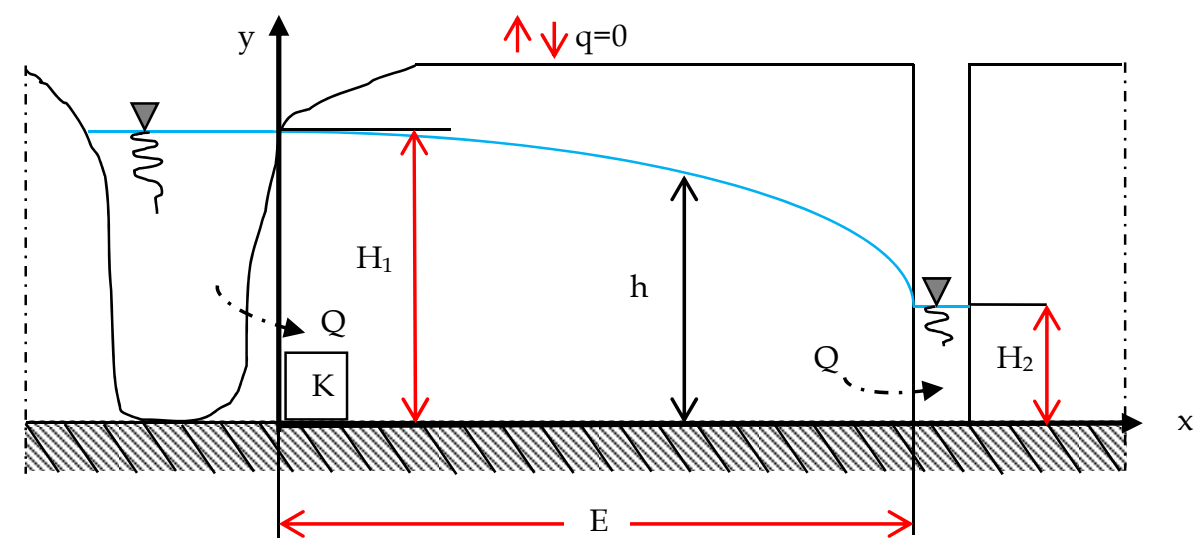

Fig. 1. Cross-sections of trench drains.

when $\mathrm{q}=0$; This equation allows us to reduce the two-dimensional flow to a one-dimensional flow by assuming parallel and horizontal stream lines.

$$
\frac{d^{2}(h)^{2}}{d x^{2}}=0
$$

Thus the solution of this equation is

$$
h^{2}=C_{1} x+C_{2}
$$

The limits conditions of this equation are

for $\mathrm{x}=0 \rightarrow \mathrm{h}=\mathrm{H}_{1}$

for $\mathrm{x}=\mathrm{E} \rightarrow \mathrm{h}=\mathrm{H}_{2}$

where

$\mathrm{H}_{1}=$ elevation of the water level in the canal (m)

$\mathrm{H}_{2}=$ elevation of the water level in the trench drain $(\mathrm{m})$

$\mathrm{E}=$ drain spacing $(\mathrm{m})$

$$
C_{1}=\frac{H_{1}^{2}-H_{2}^{2}}{E}, \quad C_{2}=H_{1}^{2}
$$




$$
h^{2}=H_{1}^{2}-\left(H_{1}^{2}-H_{2}^{2}\right) \frac{x}{E}
$$

\subsection{Darcy's law}

The movement of water through granular materials was first investigated by Darcy in 1856 when he became interested in the flow characteristics of sand filter beds. In his experiments he discovered the law governing the flow of homogeneous fluids through porous media.

Darcy's Equation can be applied to describe the flow of groundwater (Q) through a vertical plane $(h)$ at a distance $(x)$ from the ditch

$$
Q=-V \cdot S=-K \cdot I \cdot h \cdot 1=-K h \frac{\partial h}{\partial x}=-\frac{K}{2} \frac{\partial\left(h^{2}\right)}{\partial x}
$$

which can also be written as;

$$
Q=\frac{K\left(H_{1}^{2}-H_{2}^{2}\right)}{2 E}
$$

if $\pm q \neq 0$

$$
\frac{K}{2} \frac{d^{2}\left(h^{2}\right)}{d x^{2}}+q=0
$$

The solution of this equation is

$$
h^{2}=-\frac{q}{K} x^{2}+C_{1} x+C_{2}
$$

The limits conditions of this equation are

$$
\begin{aligned}
& \text { for } \mathrm{x}=0 \quad \rightarrow h=H_{1} \\
& \text { for } \mathrm{x}=\mathrm{E} \rightarrow h=H_{2}
\end{aligned}
$$

$$
h^{2}=H_{1}^{2}-\left(H_{2}^{2}-H_{1}^{2}\right) \frac{x}{E}+\frac{q}{K} x(E-x)
$$

equations (6) and (10), can be written:

$$
Q=\frac{K\left(H_{1}^{2}-H_{2}^{2}\right)}{2 E}+q\left(x-\frac{E}{2}\right)
$$

With this equation, we can determine the limit flow for $\mathrm{Q}=0$ (Fig. 2)

$$
\text { at } \begin{aligned}
\mathrm{x}=0 \rightarrow Q & =Q_{0} \\
\mathrm{x}=\mathrm{E} \rightarrow Q & =Q_{1}
\end{aligned}
$$

1. Example problem:

$A$ trench drain of $500 \mathrm{~m}$ effective length is sunk into an aquifer of permeability $\mathrm{K}=\mathbf{2}, \mathbf{0 ~} \mathrm{m} / \mathrm{d}$ at

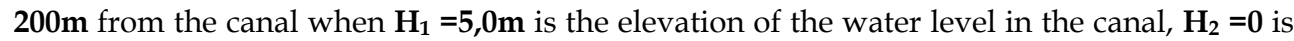
the elevation of the water level in the trench drain and the rate of recharge per unit surface area is $\mathbf{q}=\mathbf{0}, \mathbf{0 1} \mathbf{m} / \mathbf{d}$ (Fig. 3).

Calculate the flow of groundwater $\mathrm{Q}=$ ?

Solution: 
We are given:

$\mathrm{H}_{1}=5,0 \mathrm{~m} ; \mathrm{H}_{2}=0 ; \mathrm{B}=500 \mathrm{~m} ; \mathrm{K}=2,0 \mathrm{~m} / \mathrm{d} ; \mathrm{q}=0,01 \mathrm{~m} / \mathrm{d} ; \mathrm{E}=200 \mathrm{~m}$.

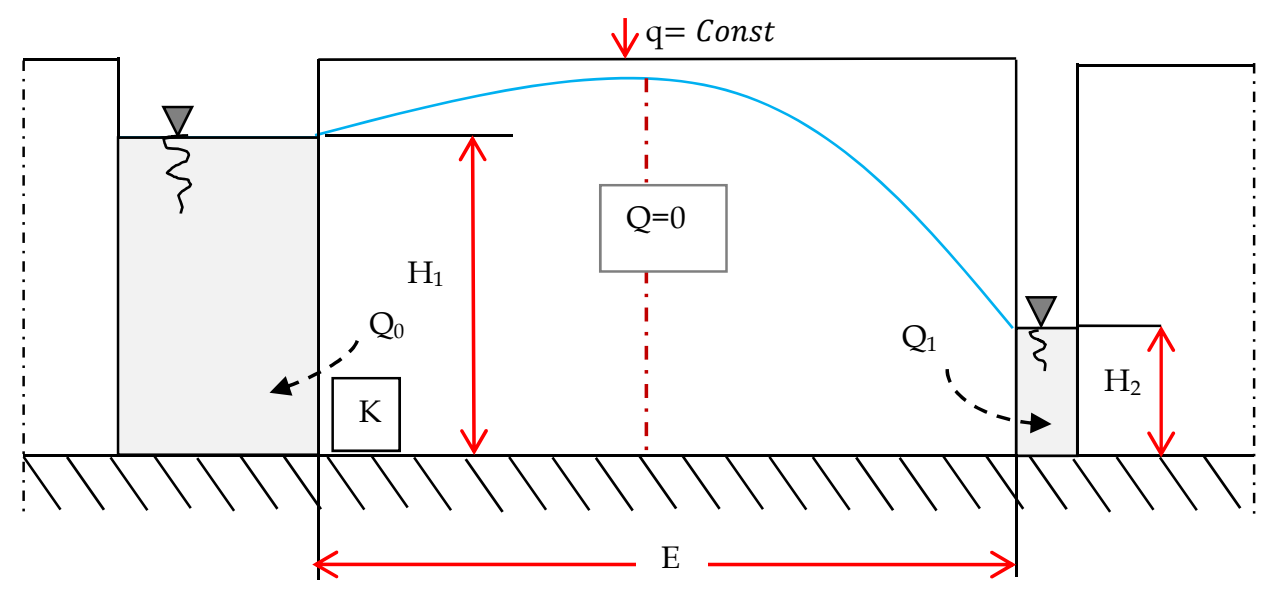

Fig. 2. Cross-sections of open field drains, showing a curved watertable.

The flow of groundwater $(\mathrm{Q})$ through a vertical plane $(h)$ at a distance $(\mathrm{x})$ from the ditch is given by this equation

$$
Q=\frac{K\left(H_{1}^{2}-H_{2}^{2}\right)}{2 E}+q\left(x-\frac{E}{2}\right)
$$

Numerical application:
a. $\quad \mathrm{x}=0 ; \rightarrow Q_{0}=\frac{2\left(5^{2}-0\right)}{2.200}+0,01\left(0-\frac{200}{2}\right)=-0,875 \frac{m^{3}}{d . m l}$
b. $\mathrm{x}=\mathrm{E} ; \rightarrow Q_{0}=\frac{50}{400}+0.01\left(200-\frac{200}{2}\right)=1,125 \frac{\mathrm{m}^{3}}{\mathrm{~d} \cdot \mathrm{ml}}$

For the whole length B, we have:

$$
\begin{gathered}
\sum Q=Q \cdot B: \sum Q_{0}=-0,875 \cdot 500=-437,5 \frac{\mathrm{m}^{3}}{\mathrm{~d}}=-5,06 \mathrm{l} / \mathrm{s} \\
\sum Q_{E}=1,125 \cdot 500=562,5 \frac{\mathrm{m}^{3}}{\mathrm{~d}}=6,51 \mathrm{l} / \mathrm{s}
\end{gathered}
$$

2sec variant: when $\mathrm{q}=0$

The discharge can be expressed by the following formula:

$$
Q=\frac{K\left(H_{1}^{2}-H_{2}^{2}\right)}{2 E}
$$

Numerical application:

$$
Q=\frac{2\left(5^{2}-0\right)}{2.200}=0,125 \frac{\mathrm{m}^{3}}{d . m l^{\prime}}
$$



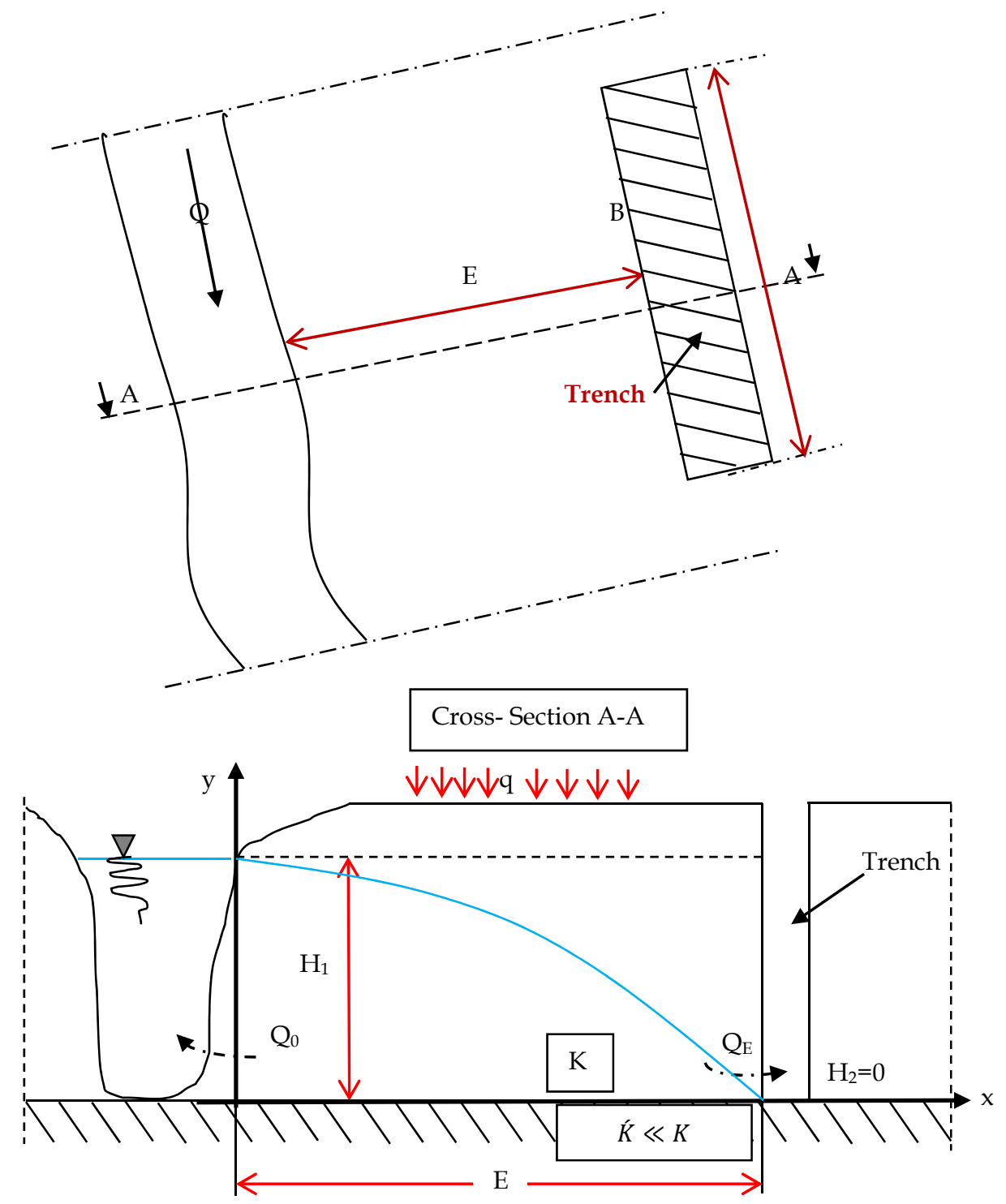

Fig. 3. Cross-sections of open field drains, showing a curved watertable under recharge from rainfall, or irrigation.

$$
\sum Q=Q \cdot B: \sum Q=0,125 \cdot 500=62.5 \frac{m^{3}}{d}=0,72 \mathrm{l} / \mathrm{s}
$$

2. Example problem:

$A$ trench drain of $500 \mathrm{~m}$ effective length is sunk into an aquifer of permeability $K$ at $200 \mathrm{~m}$ from the canal, when $\mathbf{H}_{\mathbf{1}}=\mathbf{5 , 0 \mathrm { m }}$ is the elevation of the water level in the canal, $\mathbf{H}_{\mathbf{2}}=\mathbf{0}$ is the 
elevation of the water level in the trench drain, the rate of recharge per unit surface area is

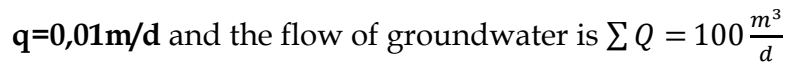

Calculate the permeability of the aquifer $K=$ ?

Solution:

We are given:

$\mathrm{H}_{1}=5,0 \mathrm{~m} ; \mathrm{H}_{2}=0 ; \mathrm{B}=500 \mathrm{~m} ; \mathrm{q}=0,01 \mathrm{~m} / \mathrm{d} ; \mathrm{E}=200 \mathrm{~m} ; \sum Q=Q . B=100 \frac{\mathrm{m}^{3}}{\mathrm{~d}}$.

the permeability of the aquifer $K$ is:

$$
K=\frac{2 Q E}{\left(H_{1}^{2}-H_{2}^{2}\right)}=\frac{2.0,200.200}{\left(5^{2}-0\right)}=\frac{80}{25}=3,2 \frac{\mathrm{m}^{3}}{d} ;
$$

the flow of groundwater Q:

$$
Q=\frac{\sum Q}{B}=\frac{100}{500}=0,2 \frac{m^{3}}{d \cdot m l}
$$

\subsection{Grapho-Analytical Method for parallel drainage}

The pumping rate is estimated by the formula of Chapman (Leonards, 1968)

$$
q=\frac{K}{r}\left(H-0,27 h_{0}\right)\left(H^{2}-h_{0}^{2}\right)
$$

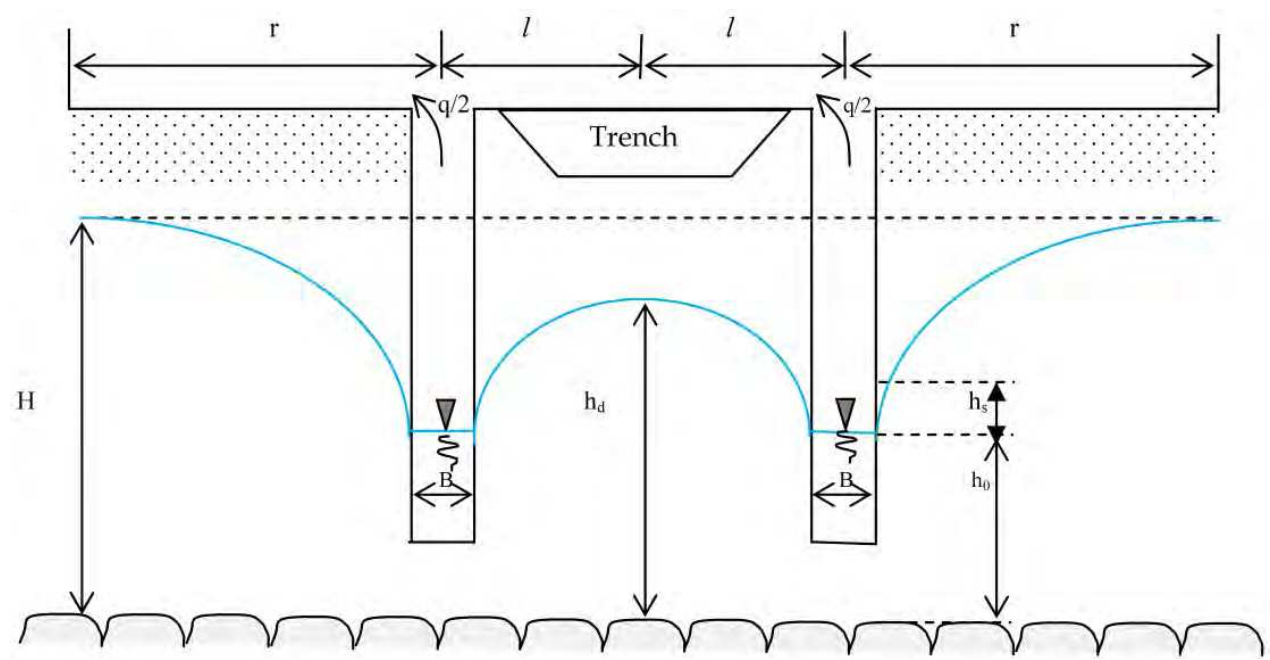

Fig. 4. Flow of groundwater to subsurface drains in shallow unconfined aquifers.

The following equation can be used to determine the elevation of the watertable midway between the drains:

$$
h_{d}=h_{0}\left[\frac{C_{1} C_{2}}{r}\left(H-h_{0}\right)+1\right]
$$


$\mathrm{C}_{1}$ and $\mathrm{C}_{2}$ are estimated by means of the curves of the flowing figure.

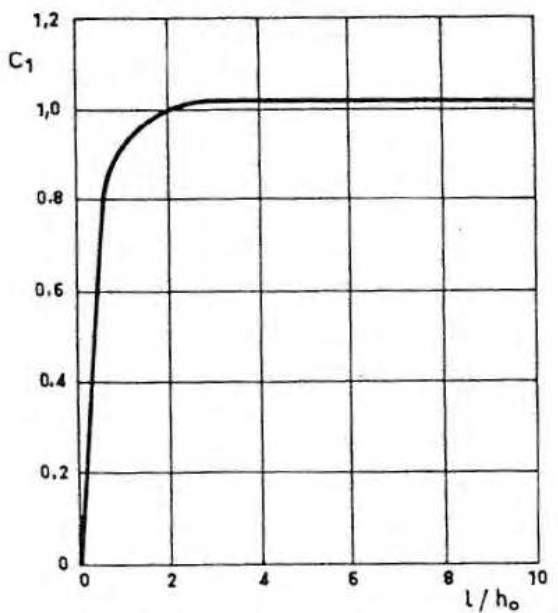

(a)

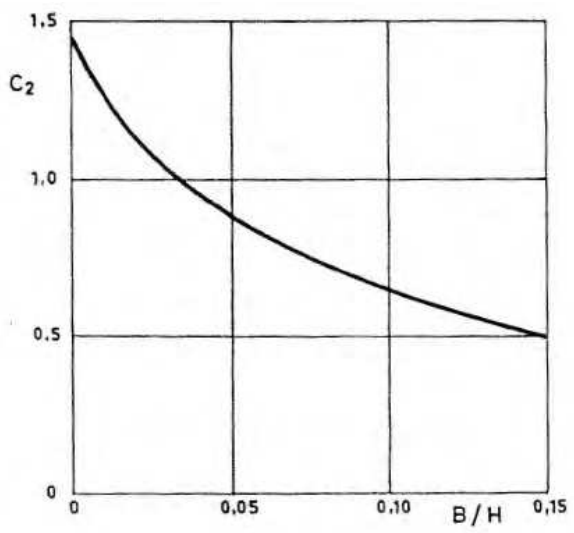

(b)

Fig. 5. Values of $\mathbf{C}_{\mathbf{1}}$ (a) and $\mathrm{C}_{2}$ (b) (from Cassan, M. (1994)).

3. Example problem:

Calculate the pumping rate $\mathrm{q}$ and the elevation of the watertable midway between the drains $h_{d}=$ ?

We have:

$\mathrm{H}=8 \mathrm{~m} ; \mathrm{h}_{0}=5,5 \mathrm{~m} ; 2 l=20 \mathrm{~m} ; \mathrm{K}=9.0 \mathrm{~m} / \mathrm{d} ; \mathrm{B}=0,8 \mathrm{~m} ; \mathrm{r}=50 \mathrm{~m}$.

Solution:

the pumping rate is:

$$
\begin{gathered}
q=\frac{K}{r}\left(H-0,27 h_{0}\right)\left(H^{2}-h_{0}^{2}\right) \\
q=\frac{9}{50}(8-0,27.5,5)\left(8^{2}-5,5^{2}\right)=4,95 \frac{m^{3}}{d \cdot m l}
\end{gathered}
$$

We can determinate $C_{1}$ and $C_{2}$ from the curves of the fig.5, we have:

$$
\begin{gathered}
\frac{a}{h_{0}}=\frac{10}{8}=1,25 \rightarrow C_{1}=0,93 \\
\frac{B}{H}=\frac{0,8}{8}=0,1 \rightarrow C_{2}=0,6
\end{gathered}
$$

And the elevation of the watertable midway between the drains:

$$
h_{d}=h_{0}\left[\frac{C_{1} C_{2}}{r}\left(H-h_{0}\right)+1\right]
$$




$$
h_{d}=5,5\left[\frac{0,93 \cdot 0,6}{50}(8-5,5)+1\right]=5,65 m
$$

The drawdown of water level is:

$$
H-h_{d}=8-5,65=2,35 m
$$

\section{Single horizontal drainage in unconfined aquifers}

\subsection{Perfect drainage}

The pumping rate is estimated by the Dupuit formula (Cassan, 1994):

$$
H_{0}^{2}-H_{p}^{2}=\frac{Q}{\pi K} \ln \frac{r}{r_{p}}
$$

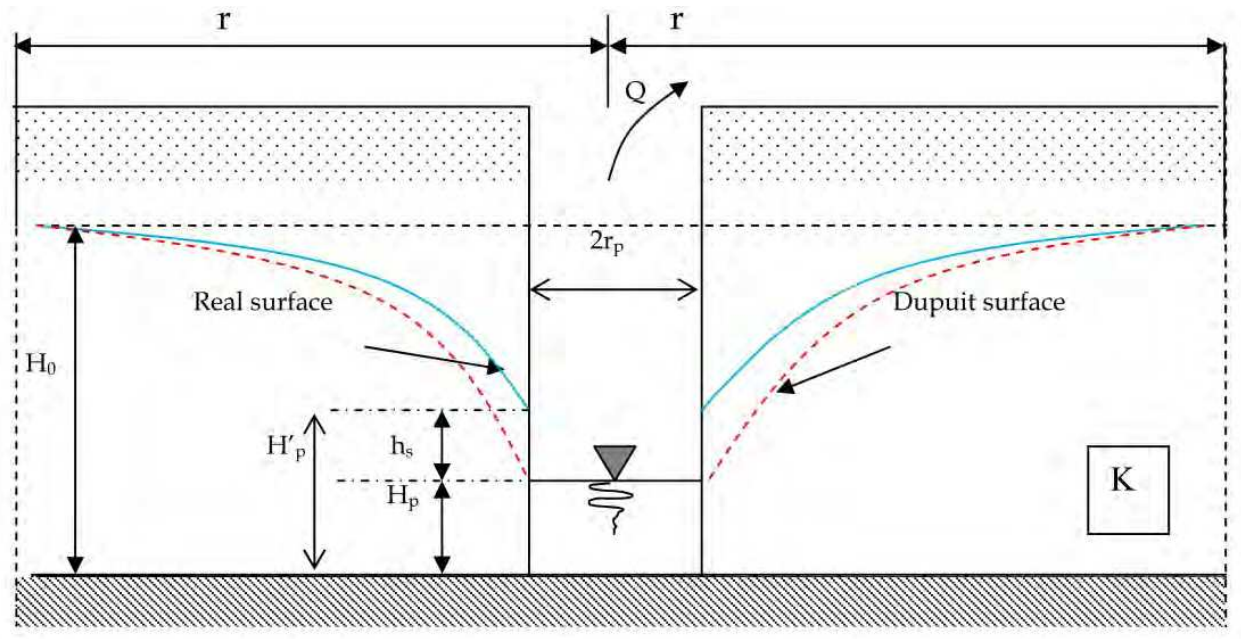

Fig. 6. The drawdown of water level in free nappe.

We can estimate the height of seepage $h_{s}$ from the abacus of schneebeli (Fig.7), if the permeability of the aquifer $K$ and the pumping rate $Q$ are known. 


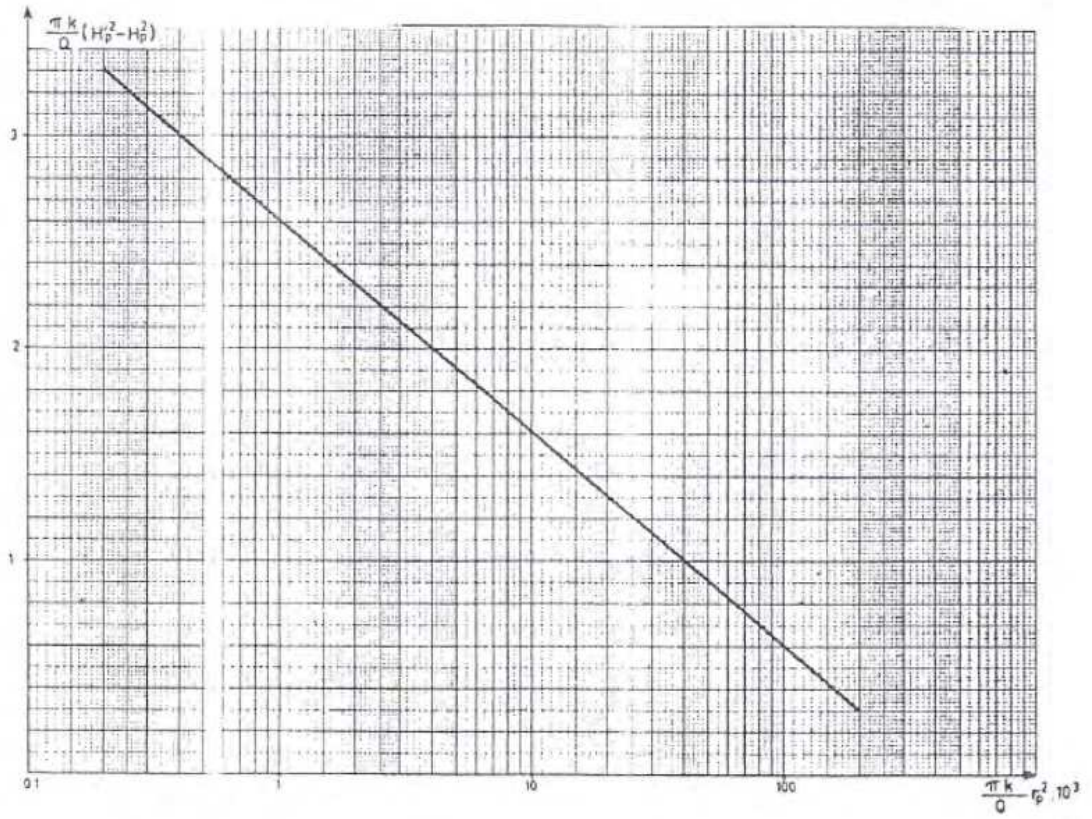

Fig. 7. Height of seepage given by the abacus of schneebeli (from Cassan, M. (1994)).

\subsection{Imperfect drainage}

The pumping rate is estimated by the flowing formula:

$$
q=\frac{K}{r}\left(H-0,27 h_{0}\right)\left(H^{2}-h_{0}^{2}\right)
$$

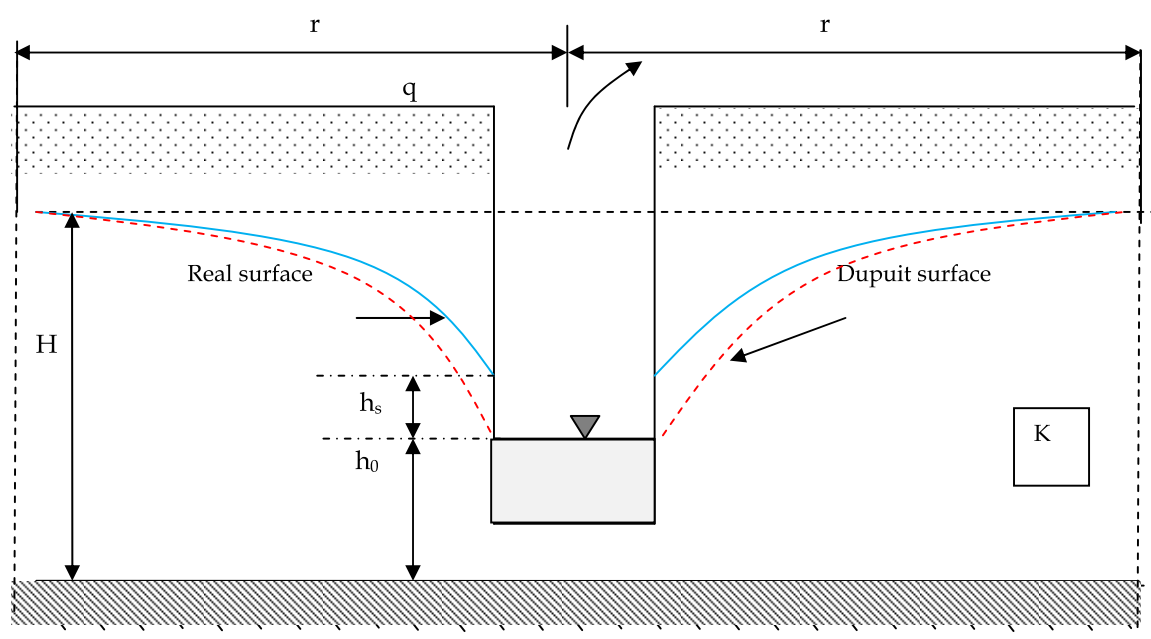

Fig. 8. Imperfect drainage in free nappe. 


\section{Single horizontal drainage in semi-captive aquifers}

The pumping rate is estimated by the flowing formula (Leonards, 1968):

$$
q=\frac{2 K D\left(H-h_{0}\right)}{l+\lambda D}
$$

where: $\lambda=$ coefficient given by the curve of the figure 10 .

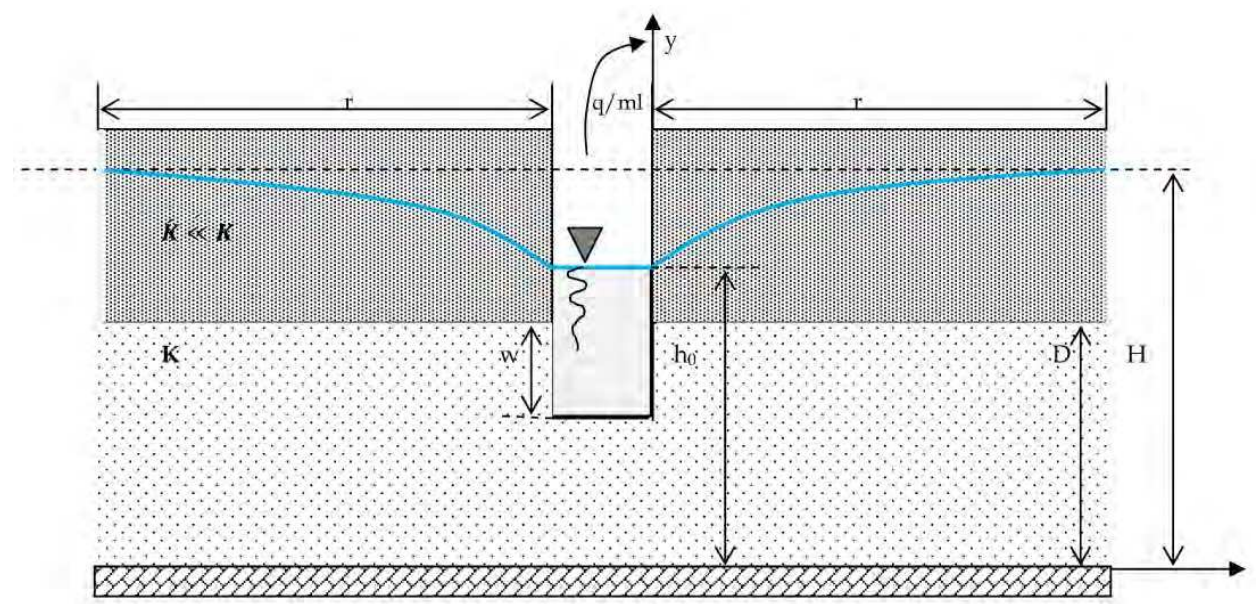

Fig. 9. Single horizontal drainage in semi-Captive aquifers.

where $r=$ radius of influence

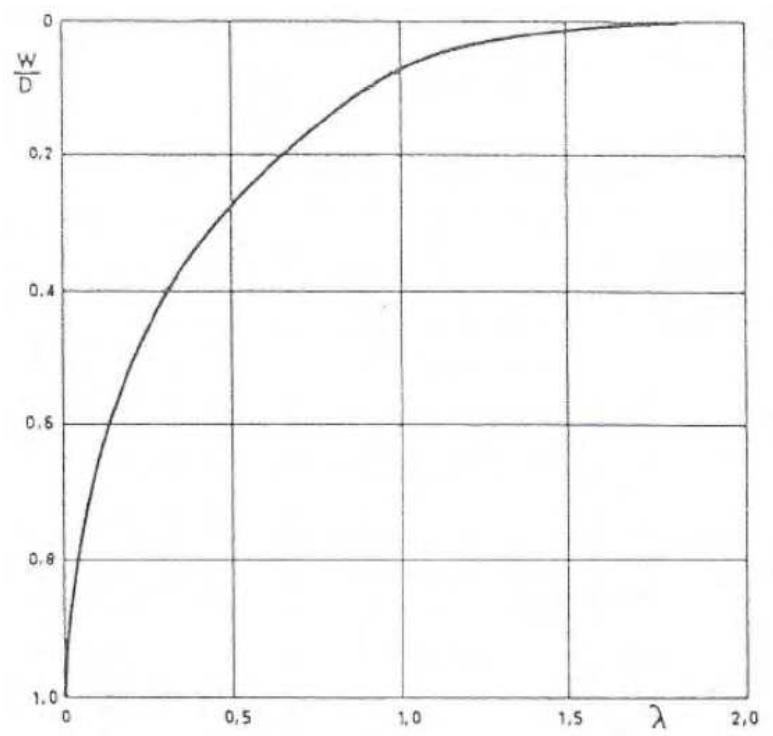

Fig. 10. Values of $\lambda$ (from Cassan, M. (1994)). 


\section{Drainage of bank storage in shallow unconfined aquifers}

\subsection{Shallow unconfined aquifers}

Unconfined aquifers are associated with the presence of a free water table, therefore the groundwater can flow in any direction: horizontal, vertical, or intermediate between them. Shallow unconfined aquifers have a shallow impermeable layer (say at 0.5 to $2 \mathrm{~m}$ below the soil surface). The flow of groundwater to subsurface drains above a shallow impermeable layer is mainly horizontal and occurs mostly above drain level (Fig. 11). In shallow unconfined aquifers, it is usually sufficient to measure the horizontal hydraulic conductivity of the soil above drain level (i.e. Ka). The recharge of water to a shallow aquifer occurs only as the percolation of rain or irrigation water; there is neither upward seepage of groundwater nor any natural drainage. Since the transmissivity of a shallow aquifer is small, the horizontal flow in the absence of subsurface drains is usually neglected (from Oosterbaan, R.J. \& Nijland, H.J. (1994)).

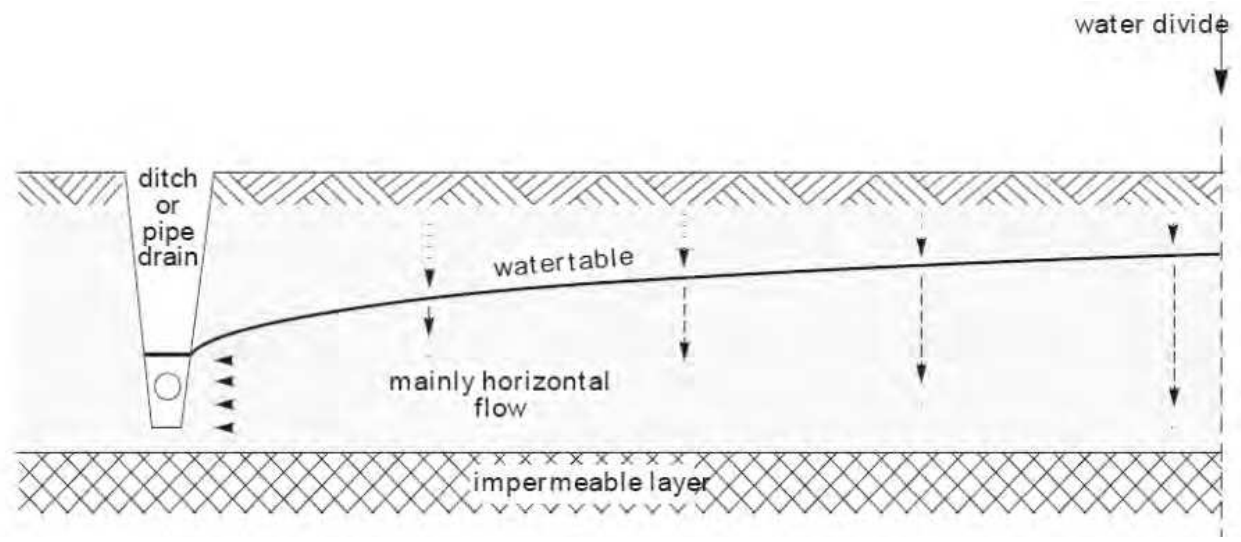

Fig. 11. Flow of groundwater to subsurface drains in shallow unconfined aquifers (from Oosterbaan, R.J. \& Nijland, H.J. (1994)).

\subsection{Methods for solving unconfined drainage}

\subsubsection{Introduction}

A large number of procedures have been used to solve seepage problems through porous medium, graphical, analytical, experimental and numerical methods were introduced in literatures to determine the hydraulic parameters of seepage through homogeneous soil.

The governing steady flow which can be described by the Laplace equation (Equation 17) is developed from application of the law of mass conservation with Darcy's Law can be solved by a graphical construction of a flow net. A flow net is a network of curves called streamlines and equipotential lines. A streamline is an imaginary line that traces the path that a particle of groundwater would follow as it flows through an aquifer. In an isotropic aquifer, streamlines are perpendicular to equipotential lines.

For isotropic soil the Laplace equation is: 


$$
\nabla^{2} h=\frac{\partial^{2} h}{\partial x^{2}}+\frac{\partial^{2} h}{\partial y^{2}}=0
$$

Where $\mathrm{h}$ is the total fluid head.

\subsubsection{Analytical methods}

Flow problems may be solved by analytical, experimental means or a combination of the two. Some analytical solutions are available for seepage flow problems. In a few cases, analytical expressions can be obtained by direct integration of the appropriate differential equation. Harr (1962) explains the use of transformations and mapping to transfer the geometry of a seepage problem from one complex plane to another. Conformal transformation techniques (conformal mapping) and velocity hodograph can also analyze a range of problems (Abd El Razek , \& Nasr, 1993).

Pavlovsky (1936, 1956) developed an approximate method which allows the piecing together of flow net fragments to develop a flow net for the total seepage problem. This method, termed the method of fragments, allows rather complicated seepage problems to be resolved by breaking them into parts, analyzing flow patterns for each, and reassembling the parts to provide an overall solution.

In 1931, Kozeny (Abd El Razek , \& Nasr, 1993) studied the problem of seepage through an earth dam on an impervious base with a parabolic upstream face and a horizontal underdrain. Using conformal mapping, he obtained a parabola for the free surface.

\subsubsection{Numerical methods}

The flow through porous media occurs usually in domain shapes that make the possibility of obtaining an analytical solution highly improbable. The nonhomogenity of the soil, the complexity of the boundaries and boundary conditions make the situation even more difficult (Hayder Hassan Al.Jairry, 2010).

The numerical solution of boundary value problems is a very old subject. In the past, the difficulty lied in the huge number of the obtained simultaneous algebraic equations, which have to be solved to reach the solution. The development of strong numerical methods can be applied to almost all types of problems of flow through porous media. These lead to the production of high quality easy to use software that can solve complicated problems and present the results in most convenient forms

Computer models are used to make acceptable approximations for the Laplace equation in complex flow conditions.

The two primary methods of numerical solution are finite difference and finite element. Both methods can be used in one-, two-, or three-dimensional modeling.

1. The finite difference method solves the Laplace equations by approximating them with a set of linear algebraic equations. The flow region is divided into a discrete rectangular grid with nodal points which are assigned values of head (known head values along fixed head boundaries or points, estimated heads for nodal points that do not have initially known head values). Using Darcy's law and the assumption that the head at a 
given node is the average of the surrounding nodes, a set of $\mathrm{N}$ linear algebraic equations with $\mathrm{N}$ unknown values of head are developed ( $\mathrm{N}$ equals number of nodes). Normally, $\mathrm{N}$ is large and relaxation methods involving iterations and the use of a computer must be applied.

2. The finite element method is a second way of numerical solution.

This method is also based on grid pattern (not necessarily rectangular) which divides the flow region into discrete elements and provides $\mathrm{N}$ equations with $\mathrm{N}$ unknowns. Material properties, such as permeability, are specified for each element and boundary conditions (heads and flow rates) are set. A system of equations is solved to compute heads at nodes and flows in the elements.

The finite element has several advantages over the finite difference method for more complex seepage problems. These include (Radhakrishnan, 1978):

a. Complex geometry including sloping layers of material can be easily accommodated.

b. By varying the size of elements, zones where seepage gradients or velocity are high can be accurately modeled.

c. Pockets of material in a layer can be modeled.

\subsubsection{Graphical method}

The graphical method can be used to solve a wider class of problems than analytical method. Its advantage is highly remarkable in case of potential flow through domains with irregular boundaries. Other types of flow such as through two dimensional anisotropic homogeneous soil or multilayers can also be treated graphically.

Flow nets are one of the most useful and accepted methods for solution of Laplace's equation (Casagrande, 1937). If boundary conditions and geometry of a flow region are known and can be displayed two dimensionally, a flow net can provide a strong visual sense of what is happening (pressures and flow quantities) in the flow region.

To draw the flow net, the following conditions are to be satisfied as follows (Harry, 1989);

1. all impermeable boundaries are streamlines,

2. all water bodies are lines of constant head (equipotential lines),

3. streamlines meet equipotential lines at right angles,

4. streamlines do not intersect one another, and

5. equipotential lines do not intersect one another.

Using the previous conditions, it is recommended to start the flow net construction by drawing the streamlines taking the advantage of the existing impermeable surfaces in the domain of flow and making sure that they meet water bodies at right angles. However, the graphical method requires a lot of experience and many trial and error works before reaching a solution with reasonable accuracy.

\subsubsection{Experimental model}

Experimental methods are considered useful for simulating the flow of water by models in laboratory. There are two types of models, electrical model, which analogous the flow of 
water by a flow of current and physical models such as sandbox model and viscous flow model (Hele-Shaw model). These methods have some inconvenient such as the complicated construction and operation. In Hele-Shaw model, the viscosity of the fluid varies with temperature, and sandbox model suffers from the difficulty of representing the correct permeability of the soil and because of the difficulties caused by capillarity. In this study we have used a sandbox model.

\subsubsection{Sand-box model}

Sand models which may use prototype materials can provide information about flow paths and head at particular points in the aquifer. We have constructed a scale model (generally sand) of the prototype in a sandbox equipped from perforated front and which allow the passage of water. When steady-state flow is reached, the flow can be traced by dye injection at various points along the upstream boundary close to the transparent wall to form the traces of streamlines, and heads determined by small piezometers (El-Masry, 1995; Khalaf Allah, 2005).

A small-scale model was built; which is geometrically similar to the real system. This model represents a homogeneous soil (bank storage in shallow unconfined aquifers) with a trench drain on an impervious foundation. Sand has been used as a permeable medium for the body of the soil, provided that its permeability is such as the flow remains laminar and that there is not any effect of distortion by capillarity (the grains should not be lower than 0,7 $\mathrm{mm}$ ) (Mallet \& Pacouant, 1951) and of gravel for the trench drain. The piezometric prickings laid out on the two zones with dimensions of the tank make it possible to know the actual values of the head of water along the trajectory of flow and highlight the burden-sharing of water in the seepages (Bear, 1972; Casagrande, 1973; Harr, 1962).

\section{Reduced model of bank storage in shallow unconfined aquifers}

\subsection{Determination of the material characteristics}

The characteristics of materials used in this model have been determined (sand for the soil and gravel for the drain) such as the vertical and horizontal permeability

\subsection{Vertical permeability}

It is given according to the Darcy' law:

$$
Q=K_{v} . S I
$$

where $\mathrm{Q}$ = quantity of discharge; $\mathrm{S}$ = cross-sectional area of flow; $\mathrm{I}=$ hydraulic gradient; $\mathrm{K}_{\mathrm{v}}$ $=$ coefficient of vertical permeability.

We obtain, $K_{v}=4.9(\mathrm{~m} /$ day $)=5,67.10^{-5}(\mathrm{~m} / \mathrm{s})$,

\subsection{Horizontal permeability}

This permeability is given according to the formula of Dupuit:

$$
Q=\frac{K_{h}\left(H_{1}^{2}-H_{2}^{2}\right)}{2 L}
$$


where $\mathrm{Q}=$ quantity of discharge; $\mathrm{H}_{1}=$ the head of water upstream; $\mathrm{H}_{2}=$ the head of water downstream; $\mathrm{L}=$ the length of the sample; $\mathrm{b}=$ the width of the sample; $\mathrm{K}_{\mathrm{h}}=$ coefficient of horizontal permeability. We obtain $\mathrm{K}_{\mathrm{h}}=43.2(\mathrm{~m} /$ day $)=5.10^{-4}(\mathrm{~m} / \mathrm{s})$.

\section{Trench drain}

\subsection{Position of the trench drain}

The best position of a trench drain in a homogeneous soil (fig.12.) can be determined according to the maximum head of water in the canal, the slope of the canal and the critical hydraulic gradient of the soil, for the case of fine sand, $I_{c r}=0,38$ (Volkov, 1986). Assuming that the curve of saturation (phreatic line) has a linear shape, we proposed the following relationship (Djehiche, 1993, Djehiche et al., 2006, Djehiche \& Kotchev, 2008).

$$
L_{d}=n H_{m}+\frac{H_{m}-H_{d}}{I_{c r}}
$$

where $\mathrm{H}_{\mathrm{m}}=$ maximum head of water in the canal; $\mathrm{h}_{\mathrm{d}}=$ imposed head of water in the trench drain; $\mathrm{I}_{\mathrm{cr}}=$ critical gradient of material used; $\mathrm{n}=$ slope of the canal; $\mathrm{L}_{\mathrm{d}}=$ position of the trench drain.

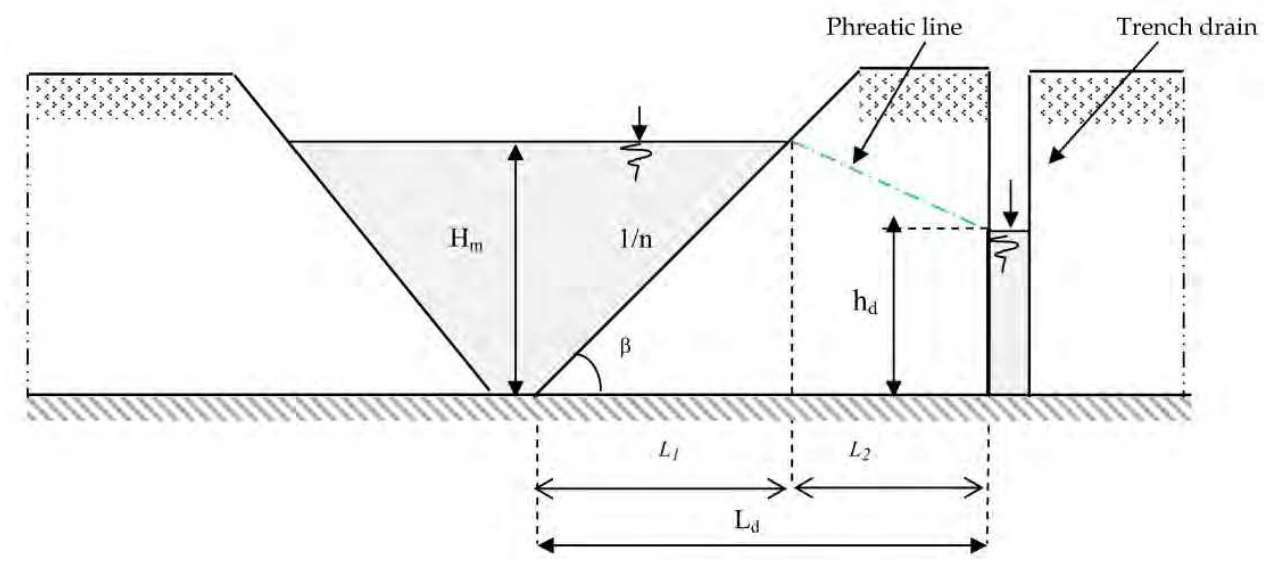

Fig. 12. The position of the trench drains.

\subsection{Water level in the trench drain}

The water level in the trench drain can be determined for a given head of water in the canal by using the two following relationships (Eq.24 and Eq.25). For the first relationship (Eq.24), we assume that the curve of saturation (phreatic line) has a linear shape, and the critical hydraulic gradient material of the soil is under the following condition:

$$
I_{c r} \leq I \leq I_{a d m} \quad \text { and } \quad I=\frac{0.82 H}{L_{d}-n H}
$$

$I_{a d m}$ - allowed infiltration gradient (Volkov, 1986). 


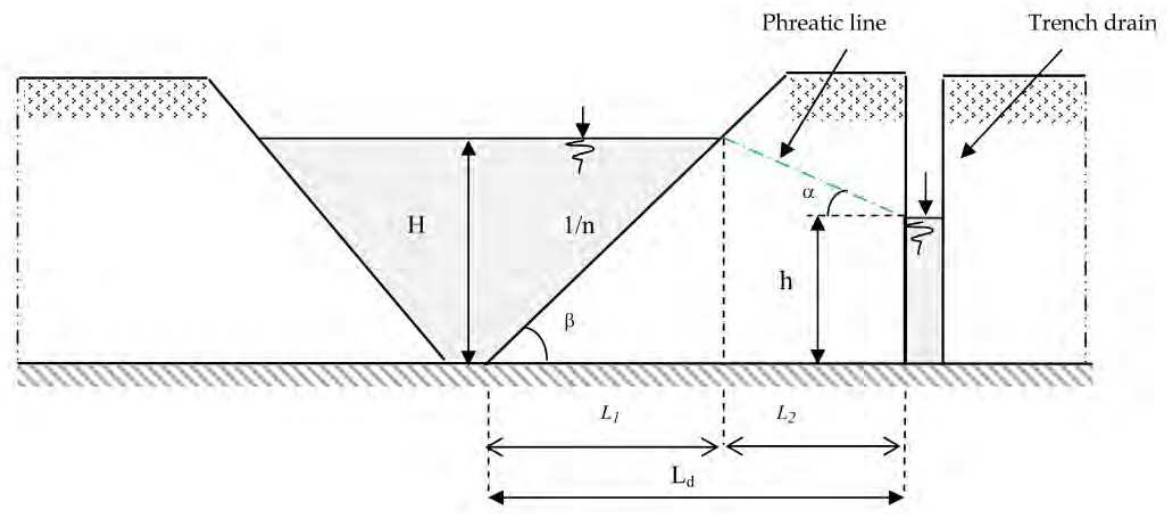

Fig. 13. the water level in the trench drain.

$$
\begin{gathered}
\tan \beta=\frac{H}{L_{1}}=\frac{1}{n} \Rightarrow L_{1}=n H \\
\tan \alpha=\frac{H-h}{L_{2}}=I_{c r} \Rightarrow L_{2}=\frac{H-h \square \square}{I_{c r}} \\
L_{d}=L_{1}+L_{2}=n H+\frac{H-h}{I_{c r}}
\end{gathered}
$$

- The first relationship is (Djehiche et al., 2006).

$$
h=H-\left(L_{d}-n H\right) I_{c r}
$$

where $\mathrm{h}=$ water level in the trench drain $[\mathrm{cm}] ; \mathrm{H}=$ the head of water in the canal $[\mathrm{cm}] ; \mathrm{I}_{\mathrm{cr}}=$ critical gradient of material used; $\mathrm{n}=$ slope of the canal; $\mathrm{L}_{\mathrm{d}}=$ position of the trench drain[cm]. A comparison between experimental, numerical and the last relationship results is presented in fig. 14 .

\subsubsection{Discussion}

Good agreement can be observed between the curves obtained by the empirical formula (24), the experimental data and the numerical results obtained with "SEEP" (Duncan, 1970). However, if we have $I<I_{c r}$ i.e. for a weak head of water the real gradient is lower than the critical gradient and we cannot use this relation.

The variation of the water level in the drain $(\mathrm{h})$ according to the head of water $(\mathrm{H})$ given by the three procedures of calculation are well adjusted except for the case $n=2.5$ where there is a small shift between the numerical results and the two others. 


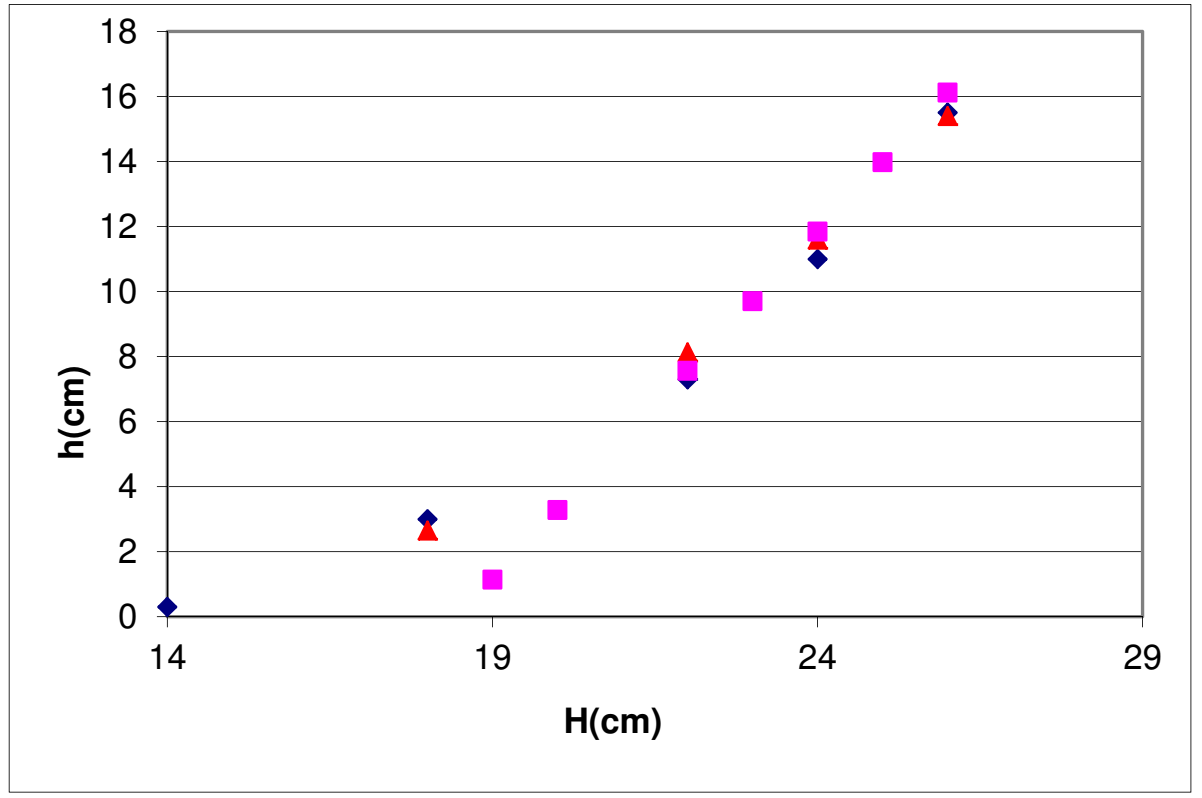

(a) $n=3,0$

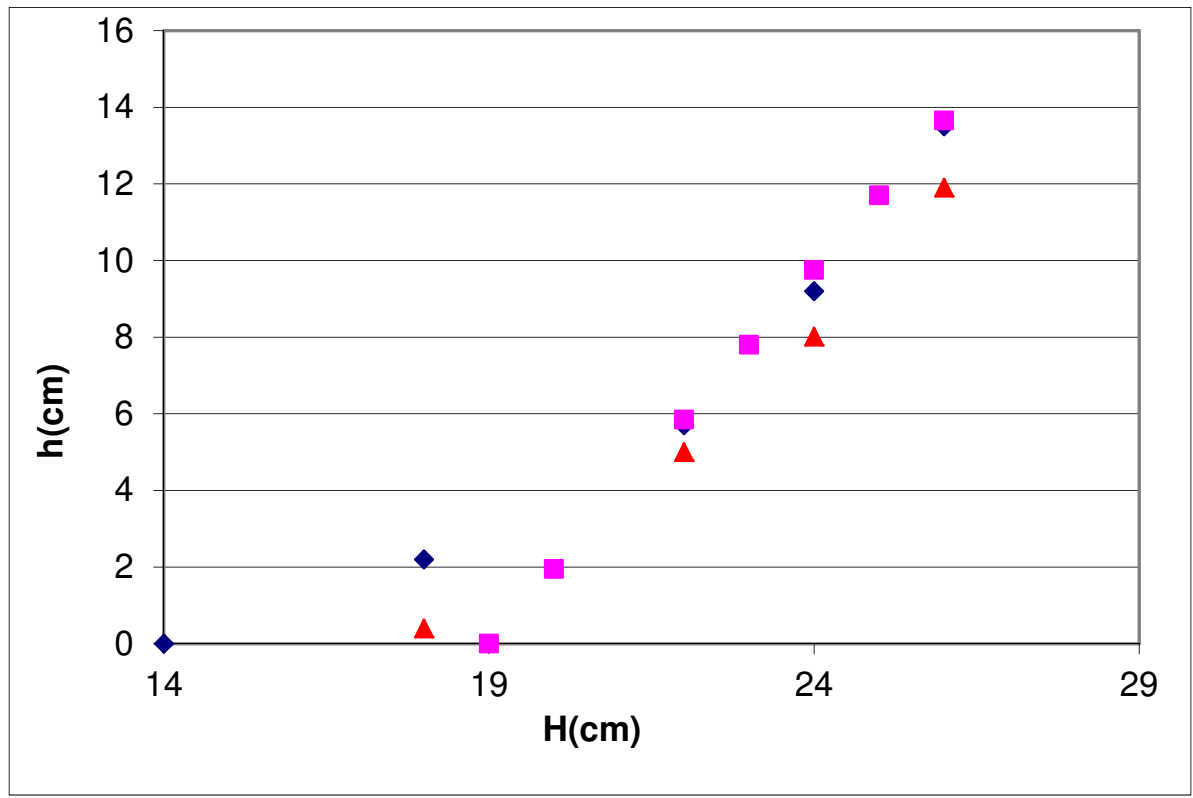

(b) $n=2,5$ 


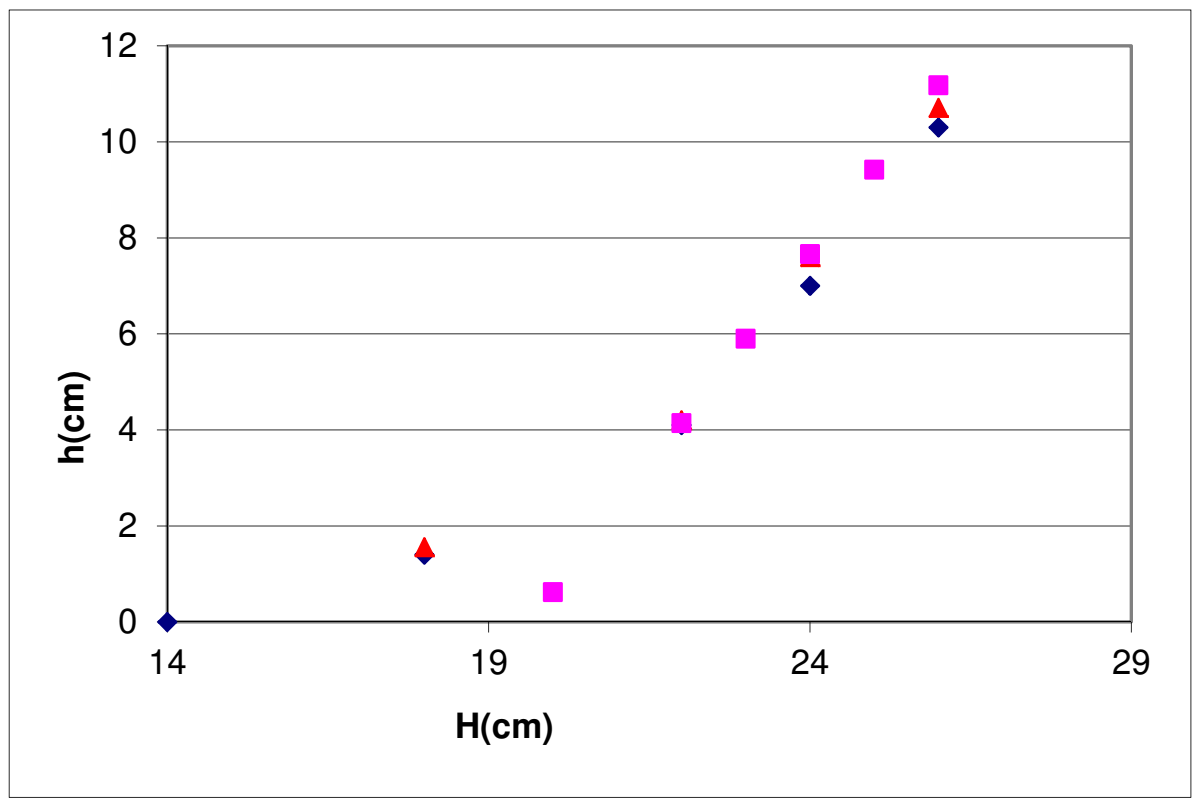

(c) $n=2,0$

Fig. 14. The lozenge represent the experimental results of the tests, the square represents the results obtained with equation (24), and the triangle represents the numerical results.

- The second relationship under the following condition:

$$
\begin{gathered}
5 \leq \frac{K_{h}}{K_{v}} \leq 30 \\
\left.h=e^{\left[\frac{0.18791 H\left(\frac{K_{h}}{K_{v}}\right)^{0.3}}{\sqrt{n}}-\frac{3.3181 \sqrt{\frac{K_{h}}{K_{v}}}}{n^{1.2}}\right.}\right]
\end{gathered}
$$

where $\mathrm{h}=$ water level in the trench $\operatorname{drain}[\mathrm{cm}] ; \mathrm{H}=$ the head of water in the canal $[\mathrm{cm}] ; \mathrm{K}_{\mathrm{h}}=$ coefficient of horizontal permeability; $\mathrm{K}_{\mathrm{v}}=$ coefficient of vertical permeability; $\mathrm{n}=$ slope of the canal.

The comparison of results of this relationship with the results of SEEP (Duncan, 1970) "software" and the experimental results is represented in fig. 15. 


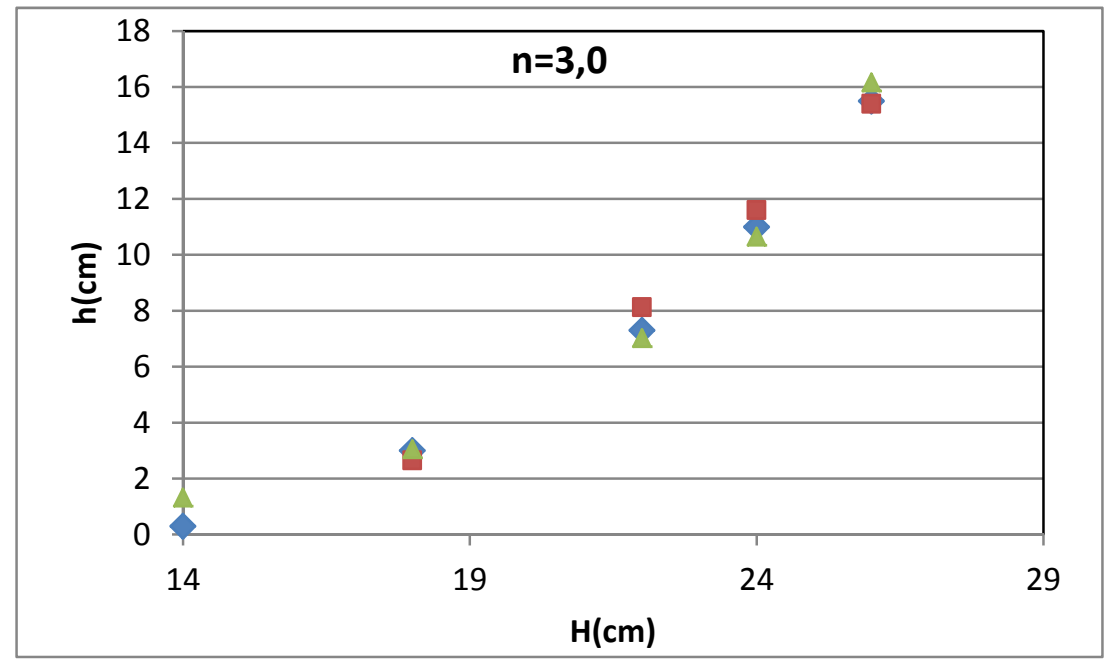

(a)

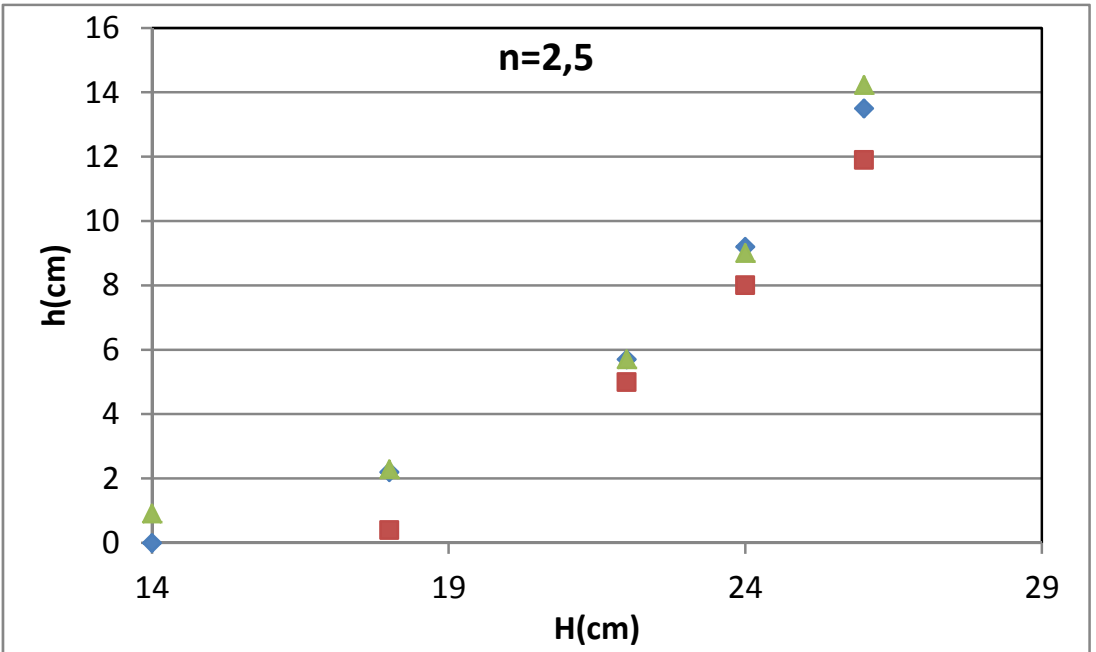

(b) 


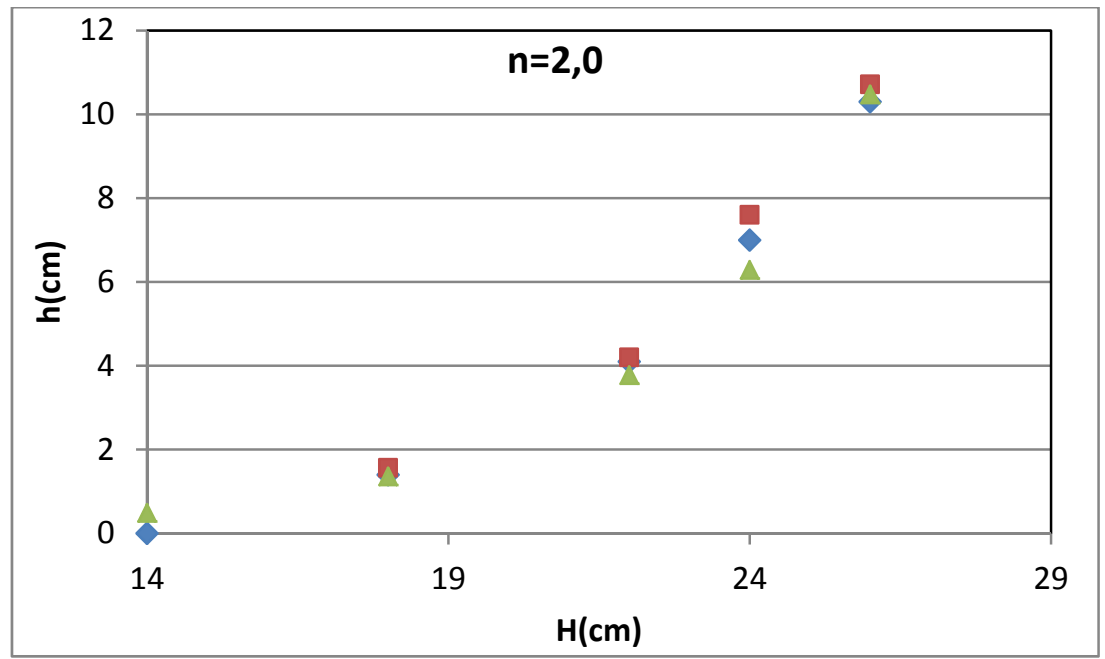

(c)

Fig. 15. The lozenge represents the experimental results of the tests, the triangle represents the results obtained with equation (25), and the square represents the numerical results: (a) $\mathrm{n}=3,0 ;(b) \mathrm{n}=2,5 ;(\mathrm{c}) \mathrm{n}=2,0$.

\subsubsection{Discussion}

We observe a good agreement between the curves obtained by the three procedures the empirical formula (25), the experimental data and the numerical results obtained with "SEEP" (Duncan, 1970).

\section{Conclusion}

The models developed in this study enable us to design the most effective position of the trench drains in the drainage of bank storage in shallow unconfined aquifers. The water level in the trench drains can be directly determined for a given head of water in the canal, slope of the canal and the permeability coefficient, therefore the seepage analysis is simplified to a certain degree and the accuracy is also satisfied based on the new approach. Moreover, these equations are simple to apply and can be used to design and analyze any homogeneous soil with a trench drains in the drainage of bank storage in shallow unconfined aquifers. These very encouraging results enable us also to extrapolated these results in the field of a network of drains in a drainage system and consider the prediction of the infiltrations through the earth dams as well as the piping phenomena which are often at the origin of many dramatic accidents.

\section{References}

Abd El Razek M., \& Nasr R. I., (1993). Evaluation of the Minimum Length of Filter in Earth Dams, Journal of Alexandria Engineering, Vol. 32, No. 4, October 1993, ISSN 11100168 . 
Bear, J.; (1972). Dynamics of Fluids in Porous Media, Elsevier, ISBN 0-444-00114-X, New York Casagrande,A. (1973). Seepage control in earth dams. J. Wiley \& Sone.

Chu , J.; Bo, M. W.; \& Choa, V. (2004). Practical considerations for using vertical drains in soil improvement projects, Geotextiles and Geomembranes , $N^{\circ} 22$ : pp 101-117, ISSN 0266-1144

Djehiche, A. (1993). Comportement des barrages en terre avec cheminée filtrante sous l'action de l'infiltration. Thèse Magister, Algeria: USTO, pp 121 (in Arabic).

Djehiche, A.; Derriche, Z. \& Kotchev, K. (2006). Control of water head in the vertical drain. Proceedings of Dams and Reservoirs, Societies and Environment in the 21 st Century, Vol.1, pp 913-916, ISBN-10: 0-415-40423-1.

Djehiche, A.; \& Kotchev, K.; (2008). Control of seepage in earth dams with a vertical drain. Chinese Journal of Geotechnical Engineering, pp 1657-1660, Vol.30, Nov (2008), ISSN 1000-4548.

Duncan, J. M. (1970). SEEP, A computer for seepage with a free surface or confined steady flow. University of California: Berkeley.

Dunglas, J. \& Loudiere, D. (1973). Nouvelle conception des drains dans les barrages en terre homogènes de petite et moyenne dimensions. La Houille Blanche, 5(6): pp. 461-465, ISSN 0018-6368.

El-Masry A. A., (1995). Unconfined Seepage through Earth Dams with Chimney Drain by Boundary Element Method", Proceeding of First Engineering conference, Mansoura, March 1995, Vol. III. pp. 357-365.

Harr, M. E.; (1962). Groundwater and Seepage, McGraw-Hill Book Company, ISBN 0-48666881-9, New York.

Harry R. Cedergren, (1989). Seepage, drainage, and flow nets. John Wiley \& Sons, Inc., New York, NY.

Hayder Hassan Al.Jairry (2010) 2D-Flow Analysis Through Zoned Earth Dam Using Finite Element Approach, Eng. \& Tech. Journal ,Vol.28, No.21,

Kahlown M. A. \& Khan A.D. (2004). Tile drainage manual. Khyaban-e-Johar, H-8/1, Islamabad - Pakistan ISBN 969-8469-13-3

Khalaf Allah S., (2005). Seepage through Earth dams with Filters, M. Sc thesis, Dept. of Irrigation and Hydraulics Eng. Mansoura university , Egypt.

Leonards, G.A., (1968), Les Fondations (traduction de "Foundation Engineering". McGrawHill New York 1962 par un groupe d'ingénieurs des Laboratoires des Ponts et Chaussées). Dunod, Paris, 1106 p

Loudiere, D. (1972). Elément théorique sur le drainage dans les barrages en terre homogènes. C.T.G.R.E.F., Nov,

Mallet, Ch. \& Pacouant, J. ; (1951). Les barrages en terre. Edition Eyrolles.

Oosterbaan, R.J. \& Nijland, H.J. (1994). Determining the saturated hydraulic conductivity. Drainage Principles and Applications. International Institute for Land Reclamation and Improvement ( ILRI), Chapter 12 in: H.P.Ritzema (Ed.) Publication 16, second revised edition, Wageningen, The Netherlands. ISBN 9070754339

Ritzema, H.P.; (1994). Subsurface Flow to Drains. Drainage Principles and Applications. International Institute for Land Reclamation and Improvement ( ILRI), Chapter 8 in: Publication 16, second revised edition, Wageningen, The Netherlands. ISBN 90 70754339 
Thieu N.T. M., Fredlund D. G., Fredlund M. D. \& Hung V. Q. (2001). Seepage Modeling in a saturated/unsaturated Soil System. International Conference on Management of the Land and Water Resources, MLWR, October 20-22, Hanoi, Vietnam.

Cassan, M. (1994). Aide-Memoire D'hydraulique Souterraine. Presses de l'école nationale des Ponts et Chaussées (ENPC) - 2ème Édition, France. ISBN-10: 2-85978-208-7

Volkov, V. (1986). Ouvrages hydrauliques. Guide de Thèse, ENSH, Blida, Algeria, pp 120-128.

Xu Y.-Q., Unami K. \& Kawachi T. (2003). Optimal hydraulic design of earth dam cross section using saturated-unsaturated seepage flow model, Advances in Water Resources, 26: pp 1-7

Zhang J., Xu Q. \& Chen Z.,( 2001). Seepage Analysis Based on the Unified Unsaturated Soil Theory, Mechanics Research Communications, , 28, No 1:pp 107-112, 


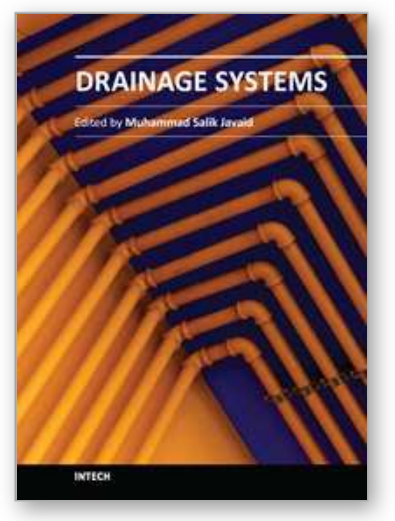

\author{
Drainage Systems \\ Edited by Prof. Muhammad Salik Javaid
}

ISBN 978-953-51-0243-4

Hard cover, 240 pages

Publisher InTech

Published online 07, March, 2012

Published in print edition March, 2012

The subject of 'drainage: draining the water off' is as important as 'irrigation: application of water', if not more. 'Drainage' has a deep impact on food security, agricultural activity, hygiene and sanitation, municipal usage, land reclamation and usage, flood and debris flow control, hydrological disaster management, ecological and environmental balance, and water resource management. 'Drainage Systems' provides the reader with a tridimensional expose of drainage in terms of sustainable systems, surface drainage and subsurface drainage. Ten eminent authors and their colleagues with varied technical backgrounds and experiences from around the world have dealt with extensive range of issues concerning the drainage phenomenon. Field engineers, hydrologists, academics and graduate students will find this book equally benefitting.

\title{
How to reference
}

In order to correctly reference this scholarly work, feel free to copy and paste the following:

Djehiche Abdelkader, Gafsi Mustapha and Kotchev Konstantin (2012). Drainage of Bank Storage in Shallow Unconfined Aquifers, Drainage Systems, Prof. Muhammad Salik Javaid (Ed.), ISBN: 978-953-51-0243-4, InTech, Available from: http://www.intechopen.com/books/drainage-systems/drainage-of-bank-storage-inshallow-unconfined-aquifers

\section{INTECH}

open science | open minds

\section{InTech Europe}

University Campus STeP Ri Slavka Krautzeka 83/A 51000 Rijeka, Croatia Phone: +385 (51) 770447 Fax: +385 (51) 686166 www.intechopen.com

\section{InTech China}

Unit 405, Office Block, Hotel Equatorial Shanghai No.65, Yan An Road (West), Shanghai, 200040, China 中国上海市延安西路65号上海国际贵都大饭店办公楼405单元 Phone: +86-21-62489820

Fax: +86-21-62489821 
(C) 2012 The Author(s). Licensee IntechOpen. This is an open access article distributed under the terms of the Creative Commons Attribution 3.0 License, which permits unrestricted use, distribution, and reproduction in any medium, provided the original work is properly cited. 